УДК 336.717.111.7

DOI: https://doi.org/10.54929/pmt-issue2-2021-8

\title{
ДИСТАНЦІЙНЕ ОБСЛУГОВУВАННЯ ЮРИДИЧНИХ ОСІБ КОМЕРЦІЙНИМИ БАНКАМИ В УКРАЇНІ
}

\section{REMOTE SERVICE OF LEGAL ENTITIES BY COMMERCIAL BANKS IN UKRAINE}

\author{
Абрамова А. C. \\ к.е.н., доцент, доцент кафедри публічних, \\ корпоративних фрінансів та фінансового посередництва, \\ Чернівецький національний університет імені Юрія Федьковича \\ ORCID ID: 0000-0003-3364-8316

\begin{abstract}
Alla Abramova
$\mathrm{PhD}$ (Economics), Associate Professor, Associate Professor of Department of Public, Corporate Finances and Financial Mediation, Yuriy Fedkovych Chernivtsi National University
\end{abstract}

У статті досліджено дистанційне обслуговування юридичних осіб комерційними банками в Україні. Визначено, що їх обслуговування являється пріоритетним напрямком розвитку комерційних банків на основі переліку аргументованих фрактів. Зазначені негативні тенденції погіршення стану банківської інфрраструктури обслуговування корпоративних клієнтів. Акцентовано увагу на сучасних вітчизняних напрямках розвитку дистанційного банківського обслуговування юридичних осіб. Виявлено основні труднощі їх банківського обслуговування. Виокремлено та аргументовано головні тенденції розвитку обслуговування досліджуваних суб'єктів на основі удосконалення компетенцій розробки цифррових систем, IT-ландшафртів, єдиного комунікаційного середовища банку, відкритості до зовнішніх інформаційних систем та єдиної біометричної системи. Ключові слова: комерційний банк, дистанційне обслуговування, юридична особа, інтернет-банкінг; sms-інформування, Call-центр.

В статье исследовано дистанционное обслуживание юридических лиц коммерческими банками Украины. Установлено, что их обслуживание является приоритетным направлением развития коммерческих банков на основе перечня аргументированных фрактов. Указаны отрицательные тенденции ухудшения состояния банковской инфрраструктуры обслуживания корпоративных клиентов. Акцентировано внимание на современных отечественных направлениях развития дистанционного банковского обслуживания юридических лиц. Выявлены основные трудности их банковского обслуживания. Аргументированы главные тенденции развития обслуживания исследуемых субъектов на основе усовершенствования компетенций разработки цифровых систем, ИТ-ландшафртов, единой коммуникационной среды банка, открытости к внешним информационным системам и единой биометрической системе. Ключевые слова: коммерческий банк, дистанционное обслуживание, юридическое лицо, интернет-банкинг; SMS-инфрормирование, Call-центр.

The article examines the remote service of legal entities by commercial banks in Ukraine. It is determined that their service is a priority for the development of commercial banks based on a list of substantiated facts. It is substantiated that the difficult economic conditions in Ukraine, exacerbated by the challenges of the COVID-19 pandemic and the use of self-isolation measures, necessitated the need for commercial banks to review strategies and tactics of interaction with customers through enhanced remote vector transformation. The negative tendencies of deterioration of the banking infrastructure of corporate customer service are noted. Emphasis is placed on modern domestic areas of development of remote banking services for legal entities. The main difficulties of their banking services are revealed. The main tendencies of development of service of researched subjects on the basis of improvement of competences of development of digital systems, IT landscapes, the uniform communication environment of bank, openness to external information systems and the uniform biometric system are argued. It is revealed that the prospects for the development of remote banking services for legal entities in Ukraine are the division of the remote service backend and the creation of an independent frontal sector of product distribution, which implements digital mechanisms of interaction with the end user - legal entity, expanding elements of product automation the bank and its partners, as well as the further formation of the ecosystem - open architecture, ARI for corporate and external information systems. It is noted that banks need more flexible, quickly adapted models of remote service, able to respond to uncertain cases in the future. The success of the digital transformation of Ukraine's banking sector in the near future will depend on whether banks can close the digital gap with world leaders, become open to cooperation with fintech companies and take advantage of the opportunities offered by the transition to customer service with smartphones. Key words: commercial bank, remote service, legal entity, internet banking; sms-informing, Call-center. 
Постановка проблеми. Складні економічні умови господарювання в Україні, посилені викликами пандемії COVID-19 та застосуванням заходів самоізоляції, зумовили потребу комерційних банків переглянути стратегії та тактику взаємодії з клієнтами шляхом посиленої трансорормації за вектором дистанційного обслуговування. Паралельним трендом взаємовідносин стало заміна сукупності банківських продуктів у напрямку індивідуального підходу клієнта за допомогою Інтернет-банкінгу. За таких умов впровадження нових технологій цифрових платежів та розширення доступу до платіжних сервісів $€$ беззаперечним рецептом успіху банківської системи.

Аналіз останніх досліджень і публікацій. Досліджуючи питання клієнтського банківського обслуговування виявлено значну кількість робіт, однак переважна більшість з них присвячені розвитку окремих банківських продуктів та механізмів, а з дослідження необхідності та проблем дистанційного обслуговування юридичних осіб $є$ певний дефріцит комплексних підходів. Загалом, розробці даного питання присвячені роботи наступних вивчених: Бондаренко А.Ф. [1], Венгерук Н.П. [2], Жаворонка А.В. [10], Іванової Т.Г. [3], Карпової Т.С. [4], Козлова В.П. [5], Ліщинської Л. [6], Моісеєнко Т.А. [7], Онищенко Ю.І. [8], Рудої О.Л. [9].

\section{Виділення невирішених раніше частин}

загальної проблеми, котрим присвячується означена стаття. У нестаціонарних умовах економічного розвитку та суспільного становища питання удосконалення та інтенсивного розвиту процедурно-інструментальних підходів дистанційного банківського обслуговування юридичних у системі забезпечення стабільності банківської діяльності та обслуговування клієнтської бази являються визначальними.

Формулювання цілей статті (постановка завдання). Метою дослідження виступає генерація комплексу заходів дистанційного банківського обслуговування юридичних осіб в Україні.

Виклад основного матеріалу дослідження. Обслуговування юридичних осіб комерційними банками $є$ одним з найбільш істотних і привабливих напрямків діяльності для будь-якого банку, що обґрунтовується фрактами високих доходів, формуванням значної частини ресурсної бази, збільшенням і розширенням кредитного та інвестиційного портфелів, обсягом проведених через банк платежів, нарощуванням показників ліквідності та платоспроможності банків і, як наслідок, їх конкурентоспроможності на ринку банківських послуг.

Основні показники функціонування юридичних осіб визначають основу розвитку економіки України та становлять не менший інтерес у системі розвитку взаємовідносин з комерційними банками (рис. 1) [11].

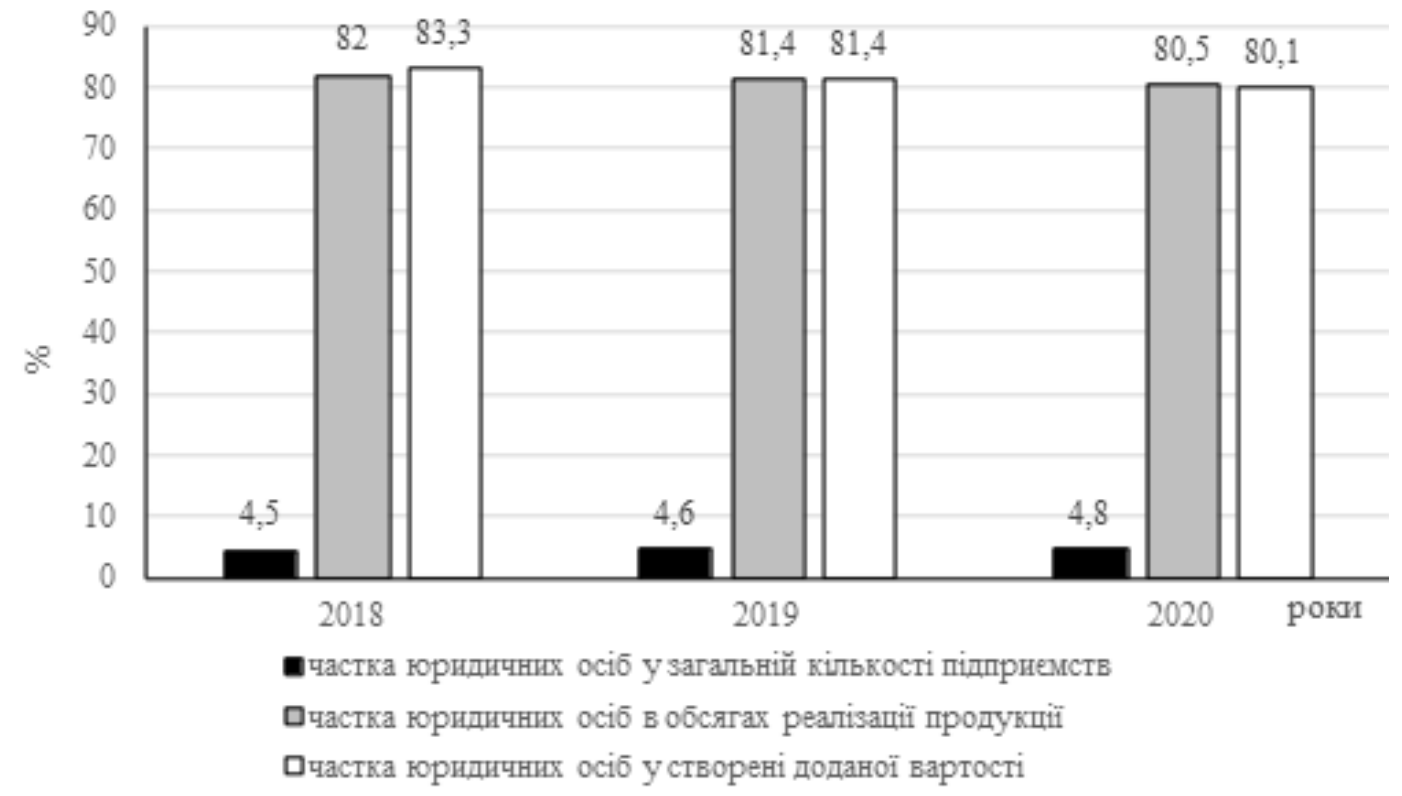

\section{Рис. 1. Динаміка основних економічних показників функціонування юридичних осіб в Україні}

Джерело: складено автором на основі [11]

Отже, юридичні особи у загальній кількості підприємств України складають від 4,5\% у 2018 році до $4,8 \%$ - у 2020, проте, незважаючи на їх незначну чисельність обсяг реалізованої продукції склав $80,5 \%$ у 2020 році проти $82 \%$ у 2018 , а питома вага у створені доданої вартості в країні за категорією витрат - у 2020 році 80,1\% проти $83,3 \%$ - у базовому році. Як бачимо, пандемічні умови ведення бізнесу 2020 року знайшли відображення у незначному, та все ж погіршенні результатів їх діяльності і участі в економічних процесах у країні. 
Поряд з цим, відмічено існування негативних тенденцій в інфраструктурі обслуговування юридичних осіб протягом досліджуваного періоду - за підсумками 2018-2020 років присутній тренд зменшення чисельності комерційних банків України та їх структурних підрозділів (рис. 2) [12].

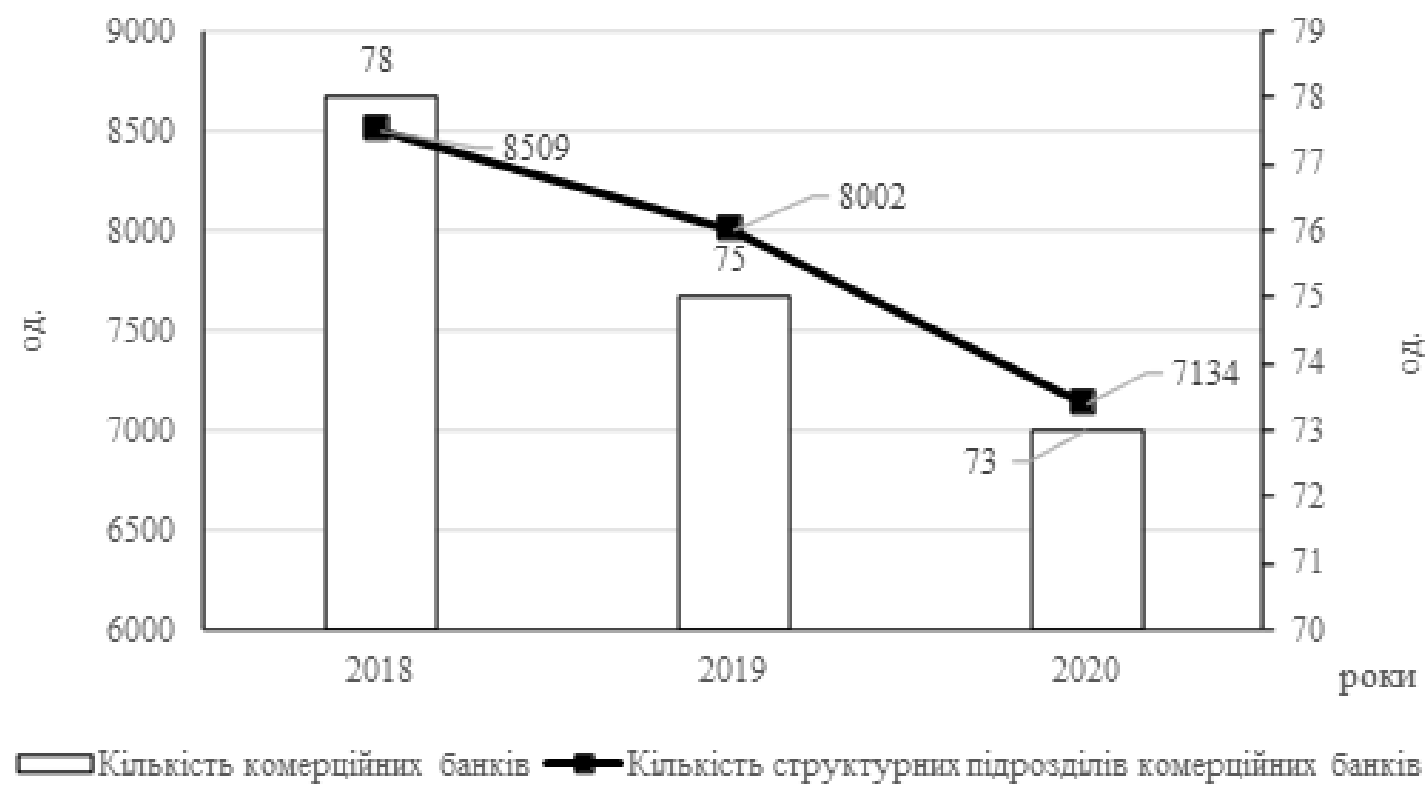

Рис. 2. Динаміка чисельності комерційних банків України та їх структурних підрозділів

Джерело: складено автором на основі [12]

Незважаючи на існуючі проблеми, викликані постійними економічними коливаннями та диспропорціями, а також невизначеністю майбутнього, комерційним банкам життєво необхідно нарощувати показники співпраці з даним клієнтським сегментом. Тому, вважаємо, що пріоритетним напрямком повинно стати саме дистанційне їх банківське обслуговування на основі on-line методів роботи.

Який же сучасний стан дистанційного обслуговування юридичних осіб комерційними банками в Україні? Свої позиції на ринку обслуговування юридичних осіб комерційні банки в Україні намагаються зміцнити за рахунок поєднання стандартних технологій і індивідуального підходу до кожного клієнта, а також активного просування новітніх продуктів та послуг, розробляючи які, фрінансові інститути чітко усвідомлюють, що обслуговування юридичних осіб - це щось набагато більше, ніж їх кредитування чи розміщення депозитних коштів, і, відповідно, заради забезпечення повної прибутковості клієнтів висувають на перший план як некредитні продукти, так і продукти і послуги, які дозволяють розвивати такий перспективний напрямок діяльності як дистанційне обслуговування корпоративних клієнтів. Аргументом цьому є той фракт, що за даними провідних вітчизняних комерційних банків України, некредитні продукти дають більше 60\% їх прибутків при роботі з корпоративними клієнтами.

Сьогодні комерційні банки являються новітніми фрінансовими організаціями, які всіма силами намагаються забезпечувати юридичних осіб електронними банківськими послугами, активно інвестують y digital і розвивають дистанційні банківські сервіси у формат 24/7 із будь-якої точки світу при наявності інтернет-каналу. Підтверджують дані процесам і офріційні статистичні дані, представлені міжнародними дослідженнями за посередництва та сприяння національних систем даних, які вказують на щорічне зростання користувачів мережею Internet, зокрема і юридичних осіб.

Послуги дистанційного обслуговування юридичних осіб в сучасних умовах надають близько 53 вітчизняних комерційних банків. 3 переліку 19 найбільших за активами банків лише 11 здійснюють надання послуг дистанційно через Інтернет. Вітчизняні банки особливу увагу приділяють соціальним мережам, а також досить активно співпрацюють через них: 49 комерційних банків вже створили і використовують в діяльності соціальні сторінки у мережі «Facebook».

Загалом, комерційні банки пропонують корпоративним клієнтам різні форми альтернативного банківського обслуговування, зокрема: інтернет-банкінг; sms-інформування - отримання інформації про залишки на розрахункових рахунках, витратних / прибуткових операціях; Call-центр - консультаційна підтримка продуктам і послугами 24/7; банкомати і пристрої самообслуговування - можливість роботи 3 готівкою без відвідування каси банку, а також бізнес-карти - можливість здійснення операцій по розрахунковому рахунку через систему банкоматів і торгово-еквайрингової мережі, підтримуючої обслуговування національної платіжної системи 
«ПРОСТІР» та міжнародних платіжних сервісів «VISA» і «MasterCard». Найбільшого розвитку у сфрері послуг інтернет-банкінгу зазнали такі фрінансово-кредитні установи, як: АТ «ПриватБанк», а також АТ «Ощадбанк».
Згідно офріційних статистичних даних НБУ найпопулярніші можливості інтернет-банкінгу, які нині використовуються юридичними особами, представлено на рис. 3 [12].

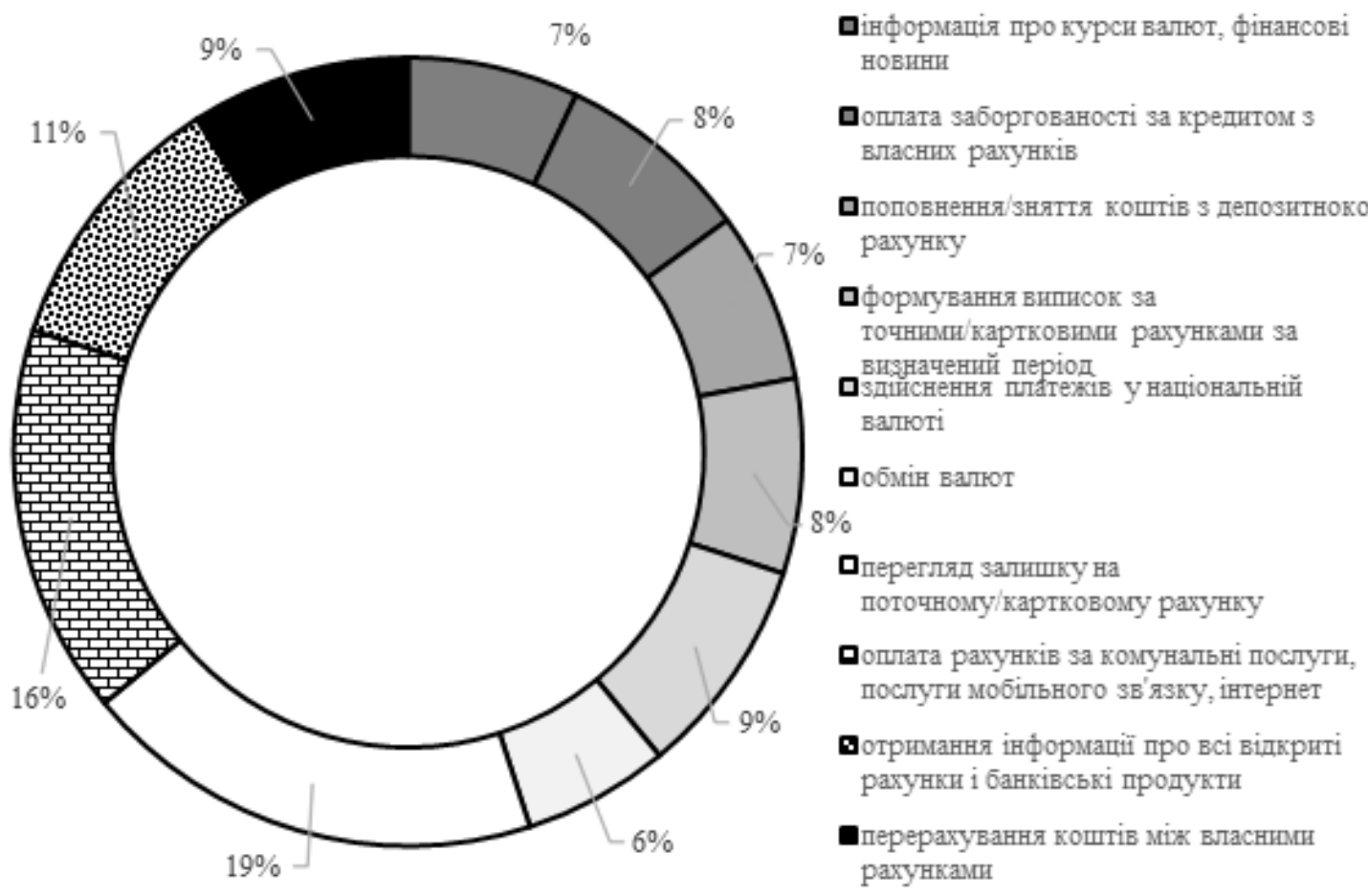

\section{Рис. 3. Частка найпопулярніших можливостей інтернет-банкінгу, які використовуються юридичними особами в Україні}

Джерело: складено автором на основі [12]

Відзначимо, що системи дистанційного банківського обслуговування реалізуються на єдиній платформі та завдяки функціонуванню національної платіжної системи, заснованої НБУ - СЕП, і не мають відмінностей у функціональності і доступному інтерфейсі для юридичних осіб по всій країні. Комерційні банки в Україні мають свої мобільні додатки для пристроїв на платформі Apple, Android, Windows Phone. Всі основні операції для роботи з платежами, рахунками, балансом / залишкам і доступні у цілодобовому режимі. Більше того, у додатках можливо зробити платіж за фротографрією рахунки на оплату, швидко виставити рахунок на оплату, онлайнчат у режим 24/7.

Попит зі сторони юридичних осіб щодо різних форм електронного обслуговування продовжуватиме зростати і надалі, адже причин до його зниження на сьогоднішній день немає. Дистанційне банківське обслуговування має ряд переваг як для банку, так і для клієнта. Перевага для клієнтів полягає в ефективному використанні тимчасово вільних грошових коштів, можливості узгодження умов розміщення депозитів, використовуючи електронні засоби зв'язку та скорочуючи витрати та час на їх обслуговування. Переваги для комерційних банків: комісійні винагороди, які дозволяють банку диверсифрікува- ти свої дохід та підвищувати стійкість у періоди кризи; ширші можливості для крос-продажів банківських продуктів та послуг, зокрема страхових внесків, збільшення клієнтської бази банків, що у майбутньому призводить до прямого зростання залишків коштів на клієнтських рахунках і, відповідно, до зростання ресурсної бази комерційного банку. Саме тому комерційним банкам в Україні необхідно постійно працювати у напрямку нарощування технічних та функціональних можливостей дистанційного обслуговування юридичних осіб [5, с. 119].

Основними труднощами обслуговування юридичних осіб в Україні встановлено загальноекономічні, зокрема: знецінення національної валюти, відтік капіталу, зменшення обсягів ЗЕД, а також проблеми фрункціонування банківської системи. До їх переліку належать: постійне зменшення чисельності комерційних банків, висока вартість розрахунково-касового обслуговування, недостатній рівень оперативності обороту грошових коштів, віддаленість від юридичної особи відділення банку, недостатня технічна підтримки і обмеженість часу ії роботи, існування спеціальних програм кредитування для партнерів-юридичних осіб, можливість відкриття валютного рахунку, наявність онлайн-банкінгу, стягування незаконної комісія за банківські операції, обме- 
жені можливості дистанційного обслуговування, недосконалі умови кредитування юридичних осіб, а також проблеми використання валютних рахунків.

Поряд з цим, сегмент дистанційного банківського обслуговування для корпоративних клієнтів традиційно є більш консервативним та інертним до інновацій. Потрібно завжди пам'ятати, що дистанційні продукти у корпоративному сегменті створюються для людей, а не для знеособлених компаній. Споживача не цікавлять внутрішня архітектура, технологічний стек, ліцензійна політика або обмеження регулятора. Для споживача будь-яке софтове рішення з самообслуговування - це зміни споживчого інтерфейсу. Будь-яке банківське дистанційне обслуговування має будуватися навколо користувацького досвіду юридичної особи, і завдання банків робити цей досвід простішим, зручнішим, фрункціональнішим, адже основним споживачем інтернет-банку для юридичної особи є співробітник фрінансової служби чи бухгалтер.

Відзначимо, що користувацький досвід роботи в частині дистанційного банківського обслуговування юридичних осіб сьогодні пропонує багато банків. Встановлення та налаштування робочого місця часто походить непросто, вимагає неймовірного терпіння та допомоги спеціаліста сфери IT. Підприємства все ще працюють з обмеженнями у роботі з Інтернет-банкінгом у популярних браузерах та різних операційних системах. Крім того, проблемним $€$ те, що інформаційна система дистанційного банківського обслуговування достовірно ідентифрікує клієнта, знає його фрінансовий стан, у 99\% випадків абсолютно не підпорядкована ні для комплексного обслуговування клієнта, ні для ролі віддаленого офрісу продажів банку.

Причин такого стану у корпоративному сегменті досить багато. Це і більш суворе нормативне регулювання, і неможливість банків самостійно та своєчасно розвивати ці важливі програмні продукти під своїми маркетинговими та бізнес-запитами, але в більшій мірі це інша спеціалізація традиційних вендорів дистанційного банківського обслуговування.

Для того, щоб на якісному рівні вирішити дану задачу, необхідний досконалий інший тип компетенцій у розробці цифрових систем, який історично сорормувався у середовищі розробки SaаA-сервісів та е-commerce-рішень. Digital-аналітика - це основне джерело прийняття рішень щодо розвитку продуктової взаємодії з юридичними особами [6, с. 207].

Успішні SaaS-сервіси та e-commerce-рішення по своїй природі реалізують місію удосконалення оцифрованих користувацьких метрик. Digital-aналітика - це сервіси для кінцевих користувачів. Прорив та зміна парадигм в оновленому дистанційному банківському обслуговуванні юридичних осіб фрормують банки-новатори. Ці банки своїми успішними прикладами задали суттєвий тренд на визначення місць традиційного дистанційного банківського обслуговування в IT-ландшафтів: це розділення бекэнда дистанційного банківського обслуговування та створення незалежного фрронтального сектору продуктової дистрибуції, у ході яких реалізуються цифрові механізми взаємодії з кінцевим користувачем. До таких трендів сьогодення відноситься:

1. Розділення класичного дистанційного банківського обслуговування на незалежний фрронт і бек. При формуванні фрронтальних платформ на перший план виходить не тільки UX-/ UI-експертиза у фрінансових сервісах, а також e-commerce-експертиза та експертиза в галузі digitel-маркетингу.

Пройшовши шлях функціонального розділення дистанційного банківського обслуговування на бекенд та фронтальну середу, банк відкриває перед собою широкі можливості розвитку фронтальної середовища згідно завдань маркетингу та бізнесу (рис. 4).

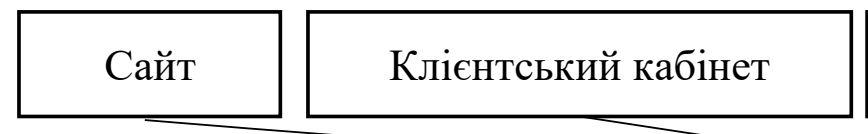

Інтернет-банкінг

Мобільний-банкінг

Backend

\section{Рис. 4. Розділення дистанційної бази обслуговування на бекенд і фрронтальну середу}

Джерело: складено автором

Фронтальний шар дистрибуції може адекватно реагувати на зміни банківського середовища. Банку стають доступні будь-які можливості у сфрері брендінгу та проектування зручних UI /
UX-сценаріїв в інтерфейсі та розширенні їх функціональних можливостей. Наслідкова транзакційна складова дистанційного обслуговування може бути розширена до елементів продуктової 
автоматизації при підключенні нових послуг та продуктів банку і його партнерів. Отримав незалежне фронтальне середовище, банки можуть об'єднувати комунікаційні засоби та розширювати продуктову матрицю для юридичних осіб.

2. Об'єднання комунікаційних середовищ і розширення продуктової матриці банку для юридичних осіб. Інструментами цього є маркетплейси, крос-продажі нефінансових сервісів, розширення продуктової лінійки за рахунок послуг і продуктів, що доповнюють розрахунково-касове обслуговування. Однак, перед тим як встати на шлях крос-продажів, завдання банку у фронталь- них середовищах дистанційного обслуговування полягає у тому, що необхідно навчитися інтерфейсно об'єднувати зону маркетингу продукту, середовище управління підключеним продуктом і середовище його продажів та підключення.

При такому підході стираються кордони між звичними, але ізольованими один від одного інформаційними середовищами: сайт банку, веб-сервіси, портальні вітрини, інтернет-банк, мобільні додатки - все це єдина комунікаційне середовище, що має тільки два стани (для авторизованого та неавторизованого користувача) (рис. 5).

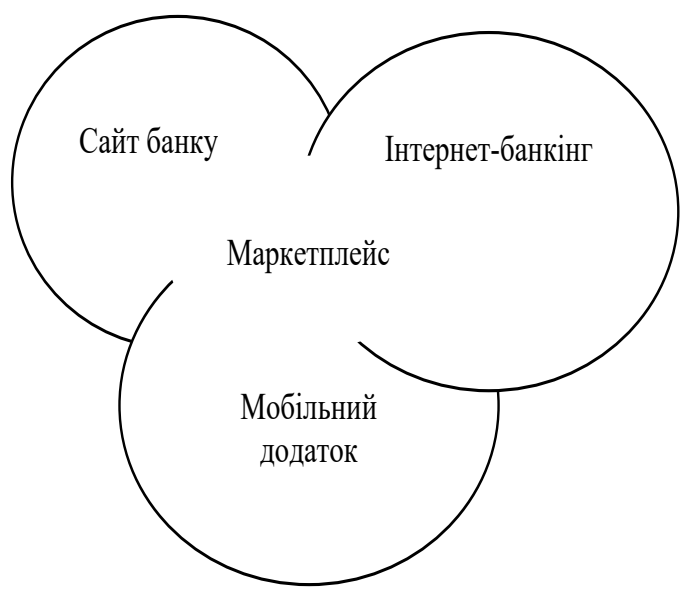

Джерело: складено автором

\section{Рис. 5. Єдине комунікаційне середовище банку}

API-інтегровані сервіси у цьому середовищі дають можливість клієнту отримувати будь-яку послугу у кілька кліків: відсутні проблеми договірних відносин з новими постачальниками, контролем оплати рахунків, реєстраціями - він просто підключає послугу, а банк списує за неї гроші.

3. Мультиформатність та мобільність. Незважаючи на вражаючі показники зростання мобільного банкінгу у роздрібному сегменті, мобільний інтернет-банкінг для юридичних осіб все ще слабо розвинений. Дається взнаки й те, що користувач - це все ще бухгалтер, для якого достатньо браузерного середовища, і більш суворі вимоги до криптографії. У багатьох банків досі немає мобільного інтернет-банкінгу для корпоративних клієнтів, а у тих, де він $€$, у більшості своїй превалює виключно оглядовий функціонал.

Як і у випадку з першим описаним трендом, траєкторію змін у корпоративному мобільному банкінгу задали банки, орієнтовані на підприємців, для яких повнофрункціональне мобільне рішення з управління фрінансами так само звично 3 точки зору автоматизації, як і управління персональними фінансами у мобільному банкінгу для фрізичних осіб.

Мобільне середовище не є заміною традицій- ному браузерному інтернет-банку: при правильному підході воно повинно дозволяти здійснювати всі типи найбільш популярних операцій. Тут краще застосувати ітеративний підхід. Так, при побудові архітектури взаємодії інформаційних систем найбільш правильним $є$ використання загального шару API для всіх фрронтальних рішень: і для браузерного інтернет-банку, і для мобільних додатків, і для b2b-платформ агентського класу. Таким чином, приступати до впровадження функціональної мобільної платформи варто після обкатки сценаріїв взаємодії зі споживачами в адаптивному браузерному середовищі і перевірки фрункціональної достатності API на наявність потрібних методів і продуктів.

Сучасний браузерний інтернет-банк повинен бути адаптований до всіх типів носіїв: від широких моніторів до екранів смарторонів. На адаптивному інтернет-банку можна налагодити і перевірити сценарії взаємодії з мобільним трафріком, перш ніж приступати до впровадження повноцінних мобільних додатків (рис. 6).

Рекомендована послідовність впровадження наступна:

1) реалізація зручного адаптивного інтерфейсу для браузерного інтернет-банку (це можна робити навіть в гайдлайнаx iOS i Android окремо); 


\begin{tabular}{|c|c|c|c|}
\hline $\begin{array}{c}\text { Браузерний } \\
\text { інтернет-банк }\end{array}$ & $\begin{array}{c}\text { Адаптована } \\
\text { версія }\end{array}$ & $\begin{array}{l}\text { Гібридний } \\
\text { додаток }\end{array}$ & $\begin{array}{c}\text { Повноцінний мобільний } \\
\text { додаток }\end{array}$ \\
\hline
\end{tabular}

Рис. 6. Етапи впровадження мобільних додатків

Джерело: складено автором

2) впровадження гібридного додатка - оболонки 3 найбільш затребуваними функціями класичного додатки і комунікаційними механіками (touch ID, push-нотифрікації) і вбудованої в оболонку браузерної частини адаптивного інтернет-банку;

3) повноцінний мобільний додаток на кросплатформенних або нативних технологіях [3, с. 90].

Існує хибна думка, що розвиток функціонального мобільного банкінгу під кожну мобільну платформу - це дуже ресурсномісткий процес. Але сьогодні існують технології одночасного розвитку як браузерних, так і мобільних середовищ з використанням загальної кодової бази, що істотно знижує ресурсомісткість i time to market функціональних компонентів незалежно від типів носіїв та операційних систем.

4. Екосистемний підхід, відкрита архітектура, API для корпоративних і зовнішніх інформаційних систем. Вирішивши проблему зручності взаємодії на призначеному для користувача рівні, сучасне корпоративне дистанційне обслуговування стає всього лише частиною великого екосистемного підходу і у питаннях автоматизації бізнесу. При такому підході дистанційного банківського обслуговування стає не тільки транзакційних інструментом, але і незамінним постачальником і реципієнтом даних для автоматизації бізнесу: таке дистанційне обслуговування володіє автоматичними інструменти інтеграції з популярними CRM-платформами, обліковими та складськими системами, білінгом, біометричними платформами, рітейл-системами і мати відкритий API для корпоративних IT-систем.

Важливо відзначити, що потенціал дистанційного банківського обслуговування з відкритою архітектурою взаємодії зі сторонніми сервісами має можливість впливати на автоматизацію і самого банку. Найпростіший приклад при операційному обслуговуванні: біометрична ідентифрікація і автоматизована процедура пошуку картки клієнта для операціоніста. Сучасне дистанційне середовище обслуговування будується на екосистемному підході, де стираються межі ізольованих раніше один від одного інформаційних систем і використовуються всілякі фрорм-фрактори зі збереженням функціональних можливостей.

Втілення такого підходу у життя об'єднує роботу багатьох традиційних банківських підрозділів. Необхідна їх злагоджена робота у форматі єдиного «проектного офрісу», а роль традиційного постачальника дистанційного банківського обслуговування все більше і більше буде зводитися до схеми бекенда-архітектури. При цьому банкам важливо міняти і підходи до управління реалізацією і бюджетування таких проектів.

3 метою забезпечення захисту розрахункових та інших операцій юридичних осіб у комерційних банках, вважаємо за необхідне, запропонувати впровадження моделі «Єдиної біометричної системи», яка б являла собою цифрову платформу, завдяки якій б можливим було дистанційно надавати фрінансові послуги на основі ідентифрікації клієнтів, зокрема юридичних осіб, за голосом або зображенням відповідальної особи відповідно до біометричних зразків.

Вважаємо, що основними перевагами такого нововведення стало б:

1) мультимодальність (складність підробки комбінації і голосу, і зображення обличчя);

2) безпечне збереження даних (біометрія та персональні дані зберігаються окремо, у зашифрованому вигляді);

3) мультивендорність (надійність та висока швидкість розпізнавання біометричних даних);

4) захист передачі даних (шифрування каналів зв'язку вітчизняними криптоалгоритмами);

5) модуль аномалій (аналіз поведінки користувачів та додатковий захист від фроду).

Банки сьогодні - це консервативні структури, однак, тільки гнучке управління вимогами та гнучкі методології реалізації дистанційного банківського обслуговування дозволяють виводити на ринок успішні продуктові кейси для клієнтів юридичних осіб.

Прогресуючі масштаби пандемії 2020-2021 років і надалі визначатимуть зростання використання та розвитку послуг дистанційного банківського обслуговування. Формування цифрових звичок у юридичних осіб зумовлює необхідність банкам привід приділяти більше уваги цій сфрері. Крім того, враховуючи хвилю кібератак у період пандемії, банкам необхідно зробити кроки у цьому напрямі та приділяти безпеці більше уваги, ніж раніше.

Висновки. Досліджено та встановлено переваги застосування дистанційного банківського обслуговування юридичних осіб в Україні як для клієнтів (ефективне використання тимчасово вільних грошових коштів, можливість узгодження умов розміщення депозитів, використовуючи електронні засоби зв'язку та скорочуючи витра- 
ти та час на їх обслуговування), так і для банків (комісійні винагороди, ширші можливості для крос-продажів продуктів та послуг, збільшення клієнтської бази і зростання ресурсної бази банку). Виявлено, що перспективами розвитку дистанційного банківського обслуговування юридичних осіб в Україні $є$ це розділення бекэнда дистанційного обслуговування та створення незалежного фрронтального сектору продуктової дистрибуції, у ході яких реалізуються цифрові механізми взаємодії з кінцевим користувачем - юридичною особою, розширення елементів продуктової автоматизації при підключенні нових послуг та продуктів банку і його партнерів, а також подальшого утворення екосистеми - відкритої архітектури, API для корпоративних і зовнішніх інформаційних систем.

Вважаємо, що банки потребують більш гнучких, швидко адаптованих моделей дистанційного обслуговування, здатних реагувати на випадки невизначені у майбутньому. Успіх цифрової трансформації банківського сектора України у найближчій перспективі залежитиме від того, чи зможуть банки скоротити цифрове відставання від світових лідерів, стати відкритими для співпраці з фінтех-компаніями та використати можливості, які відкриваються завдяки переходу на обслуговування клієнтів з допомогою смартфонів.

\section{БІБЛІОГРАФІЧНИЙ СПИСОК:}

1. Бондаренко А. Ф., Розкошна О. А. Сучасні аспекти розвитку клієнтинг-стратегії банку. URL : https://essuir. sumdu.edu.ua/bitstream-download/123456789/53504/5/Bondarenko Suchasni aspekty rozvytku.pdf (дата звернення: 01.11.2021).

2. Венгерук Н. П. Особливості функціонування дистанційних систем керування банківськими рахунками. Агросвіт. 2015. № 19. С. 35-39.

3. Іванова Т. Г. Поняття VIP-клієнта банку та підвищення ефрективності банківського обслуговування VIP-клієнтів. Вісник Академії праці і соціальних відносин Федерації профьспілок України. 2019. №1. С. 88-94. https:// doi.org/10.32843/infrastruct36-60

4. Карпова Т. С. Дистанційне банківське обслуговування: вплив на розвиток економіки України. URL: http://ena.lp.edu.ua:8080/bitstream/ntb/48493/2/2019 Karpova_T_S-Dystantsiine bankivske_25-26.pdf. (дата звернення: 01.11.2021).

5. Козлов В. П., Руденко Р. В. Становлення механізму взаємодії промислових підприємств і банків в Україні. Фінанси, облік, банки. 2017. № 1(22). С. 111-117.

6. Ліщинська Л. Основні аспекти автоматизації роботи з клієнтами засобами CRM-систем. Вісник Хмельницького національного університету. 2017. № 5(1). С. 206-209.

7. Моісеєнко Т. А. Проблеми розширення клієнтської бази в банківському секторі. Символ науки. 2016. № 2-2. C. 193-196.

8. Онищенко Ю. І., Дем'яновська Д. О. Оцінка стану дистанційного обслуговування клієнтів в банках України. Приазовський економічний вісник. 2017. Вип. 2(02). С. 141-145.

9. Руда О. Л. Дистанційне обслуговування в банківській системі. Інфраструктура ринку. 2020. № 39. С. 353-358. https://doi.org/10.32843/infrastruct39-58

10. Жаворонок А. В. Трансформація банківських продуктів і послуг у сучасних умовах. Проблеми і перспективи економіки та управління. 2019. № 2(18). С. 202-213. https://doi.org/10.25140/2411-5215-2019-2(18)-202215

11. Офріційний сайт Державної служби статистики України. URL : http://www.ukrstat.gov.ua. (дата звернення: 01.11.2021).

12. Офріційний сайт НБУ. URL : https://bank.gov.ua. (дата звернення: 01.11.2021).

13. Dubyna M., Zhavoronok A., Kudlaieva N. \& Lopashchuk I. Transformation of Household Credit Behavior in the Conditions of Digitalization of the Financial Services Market. Journal of Optimization in Industrial Engineering. 2021. 14(1). P. 97-102. DOI: https://doi.org/10.22094/JOIE.2020.677835

14. Zhavoronok A., Kholiavko N. Banking system of Ukraine: trends and prospects of development. Modern Science - Moderní věda. Praha. Česká republika, Nemoros. 2020. No 10. P. 129-142.

15. Zhavoronok A. V., Kosach I. A., Fedyshyn M. F. \& Abramova A. S. Role of commission receipts in formation of the revenue of the commercial bank. Financial and credit activity: problems of theory and practice. 2019. Vol. 4 (31). P. 22-30. DOI: https://doi.org/10.18371/fcaptp.v4i31.190781

16. Zhavoronok A. V., Fedyshyn M. F., Abramova A. S., \& Marych M. G. Management of competitiveness of the banking services. Financial and credit activity: problems of theory and practice. 2019. Vol. 1 (28). P. 64-74. DOI: https://doi.org/10.18371/fcaptp.v1i28.163340.

\section{REFERENCES:}

1. Bondarenko, A. F., Rozkoshna, O. A. (2013). Suchasni aspekty rozvytku kliientynh-stratehii banku [Modern aspects of the bank's client strategy development]. (in Ukrainian). Access mode: https://essuir.sumdu.edu.ua/ bitstream-download/123456789/53504/5/ Bondarenko_Suchasni_aspekty_rozvytku.pdf (accessed 01 November 2021).

2. Venheruk, N. P. (2015). Osoblyvosti funktsionuvannia dystantsiinykh system keruvannia bankivskymy rakhunkamy [Features of functioning of remote bank account management systems]. Ahrosvit - Agroworld. No. 19. 
Pp. 35-39. (in Ukrainian).

3. Ivanova, T. H. (2019). Poniattia VIP-kliienta banku ta pidvyshchennia efektyvnosti bankivskoho obsluhovuvannia VIP-kliientiv [The concept of VIP-client of the bank and increase the efficiency of banking services for VIP-clients]. Visnyk Akademii pratsi i sotsialnykh vidnosyn Federatsii profspilok Ukrainy - Bulletin of the Academy of Labor and Social Relations of the Federation of Trade Unions of Ukraine. No. 1. Pp. 88-94. https://doi.org/10.32843/ infrastruct36-60 (in Ukrainian).

4. Karpova, T. S. (2019). Dystantsiine bankivske obsluhovuvannia: vplyv na rozvytok ekonomiky Ukrainy [Remote banking: impact on the development of Ukraine's economy]. (in Ukrainian). Access mode: http://ena.lp.edu.ua:8080/ bitstream/ntb/48493/2/2019_Karpova_T_S-Dystantsiine_bankivske_25-26.pdf. (accessed 01 November 2021).

5. Kozlov, V. P., Rudenko, R. V. (2017). Stanovlennia mekhanizmu vzaiemodii promyslovykh pidpryiemstv i bankiv $\checkmark$ Ukraini [Formation of the mechanism of interaction of industrial enterprises and banks in Ukraine]. Finansy, oblik, banky - Finance, accounting, banks. № 1(22). Pp. 111-117. (in Ukrainian).

6. Lishchynska, L. (2017). Osnovni aspekty avtomatyzatsii roboty z kliientamy zasobamy CRM-system [The main aspects of automation of work with clients by means of CRM-systems]. Visnyk Khmelnytskoho natsionalnoho universytetu - Bulletin of Khmelnytsky National University. No. 5(1). Pp. 206-209. (in Ukrainian).

7. Moiseienko, T. A. (2016). Problemy rozshyrennia kliientskoi bazy v bankivskomu sektori [Problems of expanding the customer base in the banking sector]. Symvol nauky - Symbol of science. 2016. No. 2-2. Pp. 193-196. (in Ukrainian).

8. Onyshchenko, Yu. I., Dem'ianovska, D. O. (2017). Otsinka stanu dystantsiinoho obsluhovuvannia kliientiv v bankakh Ukrainy. [Assessment of the state of remote customer service in Ukrainian banks]. Pryazovskyi ekonomichnyi visnyk - Priazovsky Economic Bulletin. Vyp. 2(02). Pp. 141-145. (in Ukrainian).

9. Ruda, O. L. (2020). Dystantsiine obsluhovuvannia v bankivskii systemi [Remote service in the banking system]. Infrastruktura rynku - Market infrastructure. No. 39. Pp. 353-358. https://doi.org/10.32843/infrastruct39-58 (in Ukrainian).

10. Zhavoronok, A.V. (2019). Transformatsiia bankivskykh produktiv i posluh u suchasnykh umovakh [Transformation of banking products and services in modern conditions]. Problemy i perspektyvy ekonomiky ta upravlinnia - Problems and prospects of economics and management. No. 2(18). Pp. 202-213. https://doi. org/10.25140/2411-5215-2019-2(18)-202-215 (in Ukrainian).

11. Ofitsiinyi sait Derzhavnoi sluzhby statystyky Ukrainy [The State Statistics Service of Ukraine. Official site]. Access mode: http://www.ukrstat.gov.ua. (accessed 01 November 2021).

12. Ofitsiinyi sait NBU [NBU. Official site]. Access mode: https://bank.gov.ua. (accessed 01 November 2021).

13. Dubyna, M., Zhavoronok, A., Kudlaieva, N., \& Lopashchuk, I. (2021). Transformation of Household Credit Behavior in the Conditions of Digitalization of the Financial Services Market. Journal of Optimization in Industrial Engineering. 14(1). Pp. 97-102. DOI: https://doi.org/10.22094/JOIE.2020.677835

14. Zhavoronok, A., Kholiavko, N. (2020). Banking system of Ukraine: trends and prospects of development. Modern Science - Moderní věda. Praha. Česká republika, Nemoros. No 10. Pp. 129-142.

15. Zhavoronok, A. V., Kosach, I. A., Fedyshyn, M. F., \& Abramova A. S. (2019). Role of commission receipts in formation of the revenue of the commercial bank. Financial and credit activity: problems of theory and practice. Vol. 4 (31). Pp. 22-30. DOI: https://doi.org/10.18371/fcaptp.v4i31.190781

16. Zhavoronok, A. V., Fedyshyn, M. F., Abramova, A. S., \& Marych, M. G. (2019). Management of competitiveness of the banking services. Financial and credit activity: problems of theory and practice. Vol. 1 (28). Pp. 64-74. DOI: https://doi.org/10.18371/fcaptp.v1i28.163340 